Dinić S. Slavica*

Turković M. Emil ${ }^{* *}$
UDK:341.462.1

Review article

DOI: $10.5937 / \mathrm{ptp} 2101070 \mathrm{D}$

Received: February 10th 2021

Approved on: February 25th 2021

Pages: $70-85$

\title{
COMMAND RESPONSIBILITY
}

\begin{abstract}
As a part of the presentation in this paper, we will deal with one of a number of specific characteristics arisen while determining the criminal responsibility of perpetrators of international crimes, the one related to the institute of command responsibility, which are familiar with the statutes of both ad hoc tribunals (the Statute of the Tribunal in the Hague of 1993 and the International Criminal Tribunal for Rwanda of 1994), as well as the so - called the Rome Statute from 1998. In these statutes, it is set in such a way that, in one of its parts, it contradicts the basic criminal law institutes (the principle of individual subjective responsibility, the principle of justice). However, in accordance with the assumed international obligations, this institute was introduced to the criminal law system of Republic of Serbia on January 1st 2006, by prescribing, within Article 384 of the Criminal Code of Republic of Serbia, a real criminal offense of omission, which is also the subject of this paper.
\end{abstract}

Keywords: command responsibility, the Rome Statute, ad hoc tribunals, the international criminal law.

\section{Introduction}

The principle of individual, subjective responsibility, according to which „everyone is responsible only for their actions, according to which they have a certain psychological relationship and for which they can be subjected to socio-ethical reproach" (Stojanović, 2020, p. 24), today is one of the basic

\footnotetext{
${ }^{*}$ LLD. Assistant Professor at the Faculty of Security Studies, Educons University in Sremska Kamenica, Republic of Serbia. e-mail: slavicadinic@yahoo.com

** LLM Lawyer, Assistant at the Faculty of Security Studies, Educons University in Sremska Kamenica, Republic of Serbia. e-mail: emilturkovic@hotmail.com
} 
principles criminal law and in its settings, there is nothing controversial. However, the institute of command (strategic) responsibility, known in the international legal framework, is based on a position contrary to the provisions of this principle. Namely, this institute starts from the premise that a superior (in the political or military hierarchy) is responsible for the actions of his subordinates in situations when he knew that they either committed or would commit a crime, and he did not take measures to either prevent or punish them themselves (intentional form), as well as in situations where he did not know this, but had a good reason to know it (negligent form). It follows from the above that the institute of command responsibility is also contrary to the principle of justice, which starts from the fact that every sentence imposed must inevitably be fair and proportionate to the act committed (Stojanović, 2020, p. 26), because it equates someone who inadvertently failed to take measures. with the one who directly undertook the act of execution, or ordered it to be undertaken"(Stojanović, 2020, p. 17).

However, regardless of the fact that numerous complaints can be addressed to this institute, it is, with the presented shortcomings, also provided for in the Statute of the Permanent International Criminal Court, the so-called Rome Statute (Law on Ratification of the Rome Statute of the International Criminal Court, 2001, Art. 28). However, the Statute represents "progress" in the field of international criminal law, observing the current practice in this area and having in mind the statutes of two ad hoc tribunals (for the former Yugoslavia in 1993 and Rwanda in 1994). However, at the expense of all three courts, and regarding the decision they have in connection with this institute, an objection can be made that its negligent part (unconscious negligence) can in no way be combined with the intent required in all international crimes under jurisdiction. of these courts, and especially not with intent, whose existence is required in the criminal act of genocide (Stojanović, 2020, pp. 16-17), which "presupposes the existence of intent by directing it to achieve a certain goal, ie. it reinforces the volitional element in intent "(Stojanović, 2020, p. 107).

Given the fact that the Republic of Serbia has ratified the Rome Statute, our legislator had to introduce this institute into our criminal justice system as well (Stojanović \& Delić, 2020, p. 375), but this was done in an acceptable way by prescribing the real crime of omission, which has two forms, intentional and negligent (Criminal Code of the Republic of Serbia, 2006, Art. 384). 


\section{Introduction of the institute of command responsibility in the criminal justice system of the Republic of Serbia}

The development of the doctrine of command responsibility in the world was contributed to by the case of the Japanese General Tomoyuki Yamashita, most often mentioned in the literature, at the end of the Second World War, who was tried in 1945 by the American Military Commission. Yamashita was then in the so-called In the case of the "rape of Manila", he was found responsible and sentenced to death, regardless of the fact that he did not have effective control over the troops to which he was presumed, for which reason he was objectively unable to prevent crimes committed by his subordinates. The development of the institute of command responsibility, although we find its beginnings in the XVII century, in addition to the case of General Yamashita, and the so-called. The "Leipzig Trials" (the case of Landover Castle and the case of Dover Castle) were also contributed by the following cases from the period of the Second World War. The case of the Supreme Command, which referred to the generals of the Third Reich who were responsible for the German military campaign in the Soviet Union (uncompromising killing of civilians who resisted, captured Soviet commissars and commandos). The Taoist case, which referred to German military officials who carried out Hitler's order in the Balkans during World War II to shoot 50 civilians for every German soldier killed. The case of the Rehling company, which referred to certain German industrialists who were assigned a number of civilians who served as slave labor during the Second World War, due to the non-prevention of slave labor and the terrible conditions in which those persons worked. The case of Krupp and the case of the Ministry were very similar to the case of the Rehling company.

Following these cases, the institute of command responsibility was included in Additional Protocol I to the Geneva Conventions in 1977, but almost did not apply from 1945 until the ad hoc tribunal of the Security Council (the 1993 ICTY Statute and the ICC Statute ${ }^{1}$ ), and the Rwanda Court of 1994²).

\footnotetext{
${ }^{1}$ The International Tribunal for the Prosecution of Persons Responsible for Serious Violations of International Humanitarian Law in the Territory of the Former Yugoslavia after 1991 was established on May 25, 1993, by United Nations Security Council Resolution 827. It officially stopped working on December 31, 2017.

${ }^{2}$ The International Criminal Tribunal for Rwanda was established in November 1994 by United Nations Security Council Resolution 925. The scope of work of this ad hoc tribunal was to prosecute those responsible for the genocide in Rwanda and other violations of international law in Rwanda, as well as the citizens of Rwanda who, in the period from 1 January 1994 to 31 December 1994, acts committed in neighboring states. The International Criminal Tribunal for Rwanda officially ceased to function on December 31, 2015.
} 
Article 86, paragraph 2, of Additional Protocol I, ratified by the Socialist Federal Republic of Yugoslavia, reads: "The fact that a violation of the Convention or this Protocol has been committed by a subordinate does not absolve his superiors of criminal or disciplinary responsibility." or had information that enabled them to conclude under the circumstances prevailing at the time, that he had committed or would commit such an injury and that they had not taken all possible measures within their power to prevent or suppress the injury" (Edlinger, 2013 , p. 228). For the institute of command responsibility, the provision provided in Art. 87 st. 3 which contains the obligation of the commander to initiate disciplinary or criminal proceedings against the perpetrator if there is a violation of the Geneva Conventions or Additional Protocol I.

Considering the provisions of Additional Protocol I, we conclude that they equate the direct executor and the commander with a commander who knew or did not know, but could have known that his subordinate would commit, or had committed a war crime, and did not take all possible measures within the limits of its power to prevent or suppress such an act. Furthermore, as it is noticed, within this protocol, in addition to criminal liability, disciplinary liability is also mentioned, which could be applied in cases when the superior did not know that his subordinates would commit a criminal offense, so he did not prevent it, but based on available information could conclude that, while criminal responsibility should be foreseen in a situation when the superior knew that his subordinates would commit a crime (Stojanović \& Delić, 2020, pp. 373-376). However, the development of this doctrine went in the other direction (Ilić \& Dinić, 2013, p. 98).

The establishment and beginning of the work of the ad hoc tribunal were aimed at achieving international justice, ie. they represented the hope that finally serious crimes committed in the framework of armed conflicts would be prosecuted and adequately sanctioned. However, in the case of ad hoc tribunals, almost everything remained at the level of "hope", because I am the way of establishing these ad hoc tribunals, ie. their establishment by a decision of the United Nations Security Council, which had no competence for such a thing, but even more an objection of selective justice, which excludes the debate on the rule of law, because the question "why tribunals only in the case of former Yugoslavia and Rwanda, and not to the numerous cases of mass grave violations of international humanitarian law that have occurred and will occur (Stojanović, 2020, pp. 16-17), argue that expectations are not justified. All this inevitably required a solution, which was found in the establishment of a permanent international criminal 
court $^{3}$. However, even this court does not have universal jurisdiction for certain crimes, but it depends exclusively on the will of individual countries. Namely, the territorial jurisdiction of the International Criminal Court exists when a criminal offense within its actual jurisdiction is committed on the territory of one of the countries that have accepted the Rome Statute, or the offense was committed by their citizen. In the case of a country which has not accepted the jurisdiction of this Statute, it is possible for it to accept the jurisdiction of the International Criminal Court only in a specific case. In addition, the court has jurisdiction when the crime is reported to the prosecutor by the United Nations Security Council, acting on the basis of the provisions of Chapter VII of the United Nations Charter.

It follows from the above that the International Criminal Court does not have the same attitude towards the citizens of any country, and thus that it is not completely free from political influence. Thus, universal, supranational international criminal law, it is clear, has not yet been established, even if both the ad hoc tribunals and the International Criminal Court represented the steps taken to that end.

Nomotechnically, the provisions of the statutes of all these courts are at a far lower level than the criminal law norms of any national criminal law. True, the provisions of the statute of the International Criminal Court are set far better than the provisions of the statutes of both ad hoc tribunals. This progress was not difficult to achieve, given the fact that of the 34 articles of the 1993 ICTY Statute, only two relate to the general part of criminal law, and that only four articles regulate the matter of a separate act. On the other hand, the International Criminal Court was established by an international treaty (not by a decision of the Security Council, as ad hoc tribunals), further, it has some elementary institutes of general criminal law, age limit for criminal responsibility, sanity, grounds for exclusion of criminal offense, attempt, voluntary resignation), the matter of the special act was regulated in more detail and precision, and the Elements of Criminal Offenses were subsequently adopted, in which way they were more precisely set (Stojanović, 2020, p. 17), which all represents a shift in a positive direction.

However, all three courts know the institute of command responsibility, and in all of them it is prescribed in a similar way, ie. in a way that numerous objections can be addressed to him, which is also the subject of our interest in this paper.

\footnotetext{
${ }^{3}$ The International Criminal Court was established on July 17, 1998, by the Rome Statute, which entered into force on July 1, 2002, when the court began its work.
} 


\section{Command responsibility in the statutes of the ad hoc tribunal and the statute of the International Criminal Court}

Both ad hoc tribunals of the Security Council, in their statutes, as we have already stated, have a prescribed institute of command responsibility. The Statute of the Hague Tribunal from 1993 in Art. 7 st. 3, and the 1994 Statute of the International Criminal Tribunal for Rwanda in Art. 6 st. 3. Ad hoc tribunals extend the institute of command responsibility to genocide, which is not acceptable, for at least two reasons.

First, this is not provided for in the Convention on the Prevention and Punishment of the Crime of Genocide. Namely, this Convention, in Article VI, provides for the jurisdiction of the courts of the state in whose territory the act of genocide was committed, or the jurisdiction of the International Criminal Court for those states that recognize its jurisdiction. By establishing two ad hoc tribunals, the Security Council also placed the crime of genocide under their jurisdiction. However, it did so contrary to the aforementioned provision of the VI Convention, because the tribunals were established as a coercive measure of the Security Council, regardless of whether the states recognize their jurisdiction or not.

Secondly, given the nature of this crime, it is not possible at all, because in accordance with the provisions of the Convention on the Prevention and Punishment of the Crime of Genocide, the perpetrator of this crime has a mandatory existence of genocidal intent ${ }^{4}$, which is incompatible with the possibility with command responsibility, he is responsible for genocide in a situation where there is unconscious negligence.

Furthermore, the statutes of the ad hoc tribunal do not limit the application of the institute of command responsibility only to military officers, but more broadly to civilian superiors. In addition, command responsibility does not only apply to de jure, but also to de facto superiors, so the fact that any crime within the jurisdiction of the Tribunal was committed by a subordinate does not absolve his superior from criminal responsibility if he knew, or had reason to know that the subordinate would commit the crime or that he committed it, and the superior failed to take the necessary and reasonable measures to prevent the commission of such an act or failed to punish its perpetrators (Ilić \& Dinić, 2013, pp. 98 -99).

\footnotetext{
${ }^{4}$ Genocidal intent means the intention to completely or partially destroy a group, and the perpetrator's guilt requires direct intent. Intention implies the existence of a voluntary element of high intensity.
} 
As we have already stated, the statute of the permanent International Criminal Court is far more advanced, ie. more orderly and precisely set by the statute of the ad hoc tribunal of the Security Council. But, regardless of that, the statute of the permanent International Criminal Court retains the part that is disputable, ie. the commander equates with the perpetrator even when he did not know that the forces under his command are committing a crime or are preparing to commit it, as well as when he does not take the necessary measures to punish the perpetrators, ie when he fails to report the crime to the competent authorities (Article 28, point (a). Therefore, it is clear that this court also maintains that the superior is also responsible forunconscious negligence for intentional crimes, however, makes a distinction in terms of responsibility between military and civilian superiors (Article 28, item b), in the sense that in relation to civilian officers somewhat stricter conditions are set for their command responsibility, so that the existence of at least conscious negligence in relation to the act committed by subordinates.

\section{Command responsibility in the Criminal Code of the Republic of Serbia}

From the above, the conclusion unequivocally follows that the laws of European countries, the institute of command responsibility, were not known until recently. Furthermore, as we have already stated, this institute has disputable elements, but it is not disputable in its entirety. Namely, the institutes of criminal law that are generally accepted can be applied to one of its parts. These are cases when superiors know that their subordinates are preparing a crime, and they have the duty and the opportunity to take measures to prevent the commission of that crime, which their superiors do not do, and the crime, for that reason, is committed (direct and possible intent). In this situation, we have an intentional criminal offense of omission, in which case we can equate the superior with the perpetrator, ie. the ordering party of the criminal offense because, the truth is, there is no explicit order to commit the criminal offense, but the objective superior allowed it (by wanting it, or by agreeing to it). Accordingly, the institute of complicity committed by omission, or the institute of complicity in a broader sense, could be applied here, provided that such omission was not essential for the commission of the criminal offense.

However, the problem, as we have already stated, occurs in another part of this institute, within which only the existence of unconscious negligence is required, which is absolutely incompatible with the nature of international 
crimes in the narrower sense $\mathrm{e}^{5}$, because they are always intentional. Neither criminologically nor legally dogmatically is it acceptable to equate a superior who ordered the commission of a crime and a superior who did not know that his subordinate would commit the crime (regardless of the fact that he had a good reason to know it), even when such a possibility is only allowed, but held lightly that it would not happen, or that he would be able to prevent it (unconscious and conscious negligence). There is a possibility that this is an incompetent superior, who should be replaced, disciplined, but in no way equated with the perpetrator of serious intentional crimes, because in that case it would be an objective responsibility (Stojanović \& Delić, 2020, pp. 373- 376).

The issue of introducing this institute into our criminal legislation, as we have already stated, was opened by the ratification of the Rome Statute. The main problem, as we have already stated, was that this institute equated the involuntary failure to prevent the commission of a criminal offense or report its perpetrator, with the intentional commission of a criminal offense that was not prevented or reported. Our legislator overcame this by not prescribing the negligent part of command responsibility as a form of responsibility in the form of a general institute, but especially incriminating it as responsibility for the crime of failing to take measures that the superior was obliged to take and which would prevent the execution of certain criminal acts, but in no case as responsibility for those acts themselves. In this way, our national legislation has been harmonized with the Rome Statute, while the institute of individual subjective responsibility has not been violated. Thus, in the Criminal Code of the Republic of Serbia, in Chapter XXXIV, entitled: Criminal offenses against humanity and other goods protected by international law, Article 384 contains the offense: Non-prevention of criminal offenses against humanity and other goods protected by international law, which has two basic (paragraphs 1 and 2) and one negligent form (paragraph 3).

The first basic form (paragraph 1) consists in failing to take measures to prevent criminal offenses under Art. 370 to 374, Article 376, Art. 378 to 381 and Article 383 (all the listed acts are systematized within Chapter XXXIV of the Criminal Code of the Republic of Serbia). This criminal offense can be committed only by omission, so it is a real criminal offense of omission. Namely, the perpetrator fails to take the measures he could and was obliged to take in order to prevent the crime. There are two possible situations. In the first situation, the forces commanded or controlled by the perpetrator of a particular crime may prepare the commission of the crime, while in the second situation, they may

\footnotetext{
${ }^{5}$ In the so-called international crimes in the narrower sense include: war crimes, crimes against peace, crimes against humanity and crimes of genocide.
} 
begin its commission. However, for a crime to exist, any of the listed crimes (Articles 370 to 374, Article 376, Articles 378 to 381 and Article 383) must be completed due to omission. In addition, it is necessary that there is a causal link between the omission of the perpetrator and the commission of the crime by subordinates. The perpetrator may be a military commander who either formally or de facto controls the persons who commit or prepare any of the listed crimes. At the subjective level, the existence of intent is necessary, as well as the knowledge that the forces commanded or controlled by the perpetrator prepare or have begun the commission of the stated criminal offenses.

In the second basic form (paragraph 2), only the civilian superior appears as the executor, unlike the first form (paragraph 1), where the military commander or the person who actually performs that function appears as the executor.

The perpetrator of both forms of this crime is punished by the punishment prescribed for the criminal offense that was not prevented.

The third form of this crime, the negligent form (paragraph 3), refers to both basic forms, and includes both conscious and unconscious negligence. In this way, our legislator went further than the solution in the Rome Statute, because even in the case of a civilian superior (Article 384, paragraph 2), an involuntary criminal offense also exists when it comes to unconscious negligence.

The prescribed punishment for this negligent form is imprisonment for a term of six months to five years.

In order to consistently apply the ratified Rome Statute in terms of command responsibility, a more serious form of the crime is also important: Failure to report the crime and the perpetrator, from Article 332 para. 3 , Chapter XVIII, whose protective object is the judiciary, ie the unhindered performance of a judicial function (Čejović \& Kulić, 2012, pp. 588-589).

Namely, paragraph 3 of Article 332, stipulates that conscientious failure to report a criminal act of his subordinate, which he committed in the performance of his official, military or work duty, and for which a prison sentence of thirty to forty years may be imposed by law, may executed only by an official or responsible person. The prescribed punishment for this crime is imprisonment from six months to five years.

\section{Trial for command responsibility in the Republic of Serbia}

When it comes to the issue of punishment for crimes committed during the wars of the 1990s, we often, unfortunately, refer to the process of joining the European Union. We say "unfortunately", because often in our society there are not enough arguments that determining responsibility for such crimes is an 
obligation both legal (even before these wars very clearly established by both international and national law) and moral, which, as well as legal, does not suffers excuses. Namely, the obligation to punish these crimes would also exist if membership in the European Union was not a strategic goal of the Republic of Serbia.

Speaking of European integration, we cannot ignore the fact that the accession process itself involves a continuous assessment of progress in many areas, including a commitment to punishing those responsible for war crimes, genocide and crimes against humanity, which fall within the candidate country's general obligations. as one of the political criteria for accession to the European Union. These criteria include the issue of cooperation with the countries of the region, which is certainly influenced, among other things, by the prosecution of crimes committed during the mentioned wars. The punishment of those responsible for these crimes is also monitored through the negotiating Chapter 23, which deals with human rights, independence and an efficient judiciary.

However, the prosecution of persons on the basis of command responsibility in the Republic of Serbia has so far been largely absent. This was also stated by the European Commission in its Progress Report on Serbia for 2018, explicitly emphasizing that the Republic of Serbia has not filed a single indictment against senior military and police officials for war crimes. Similar allegations can be found in the Progress Report of Serbia for 2019. The same statement, in their statements or critical reports, is also made by the United Nations Committee against Torture, the Organization for Security and Cooperation in Europe, as well as domestic (primarily the Humanitarian Law Center) and international civil society organizations (Amnesty International and others). The reason for this situation in our country is often the legal argument that the institute of command responsibility at the time of the commission of criminal offenses in relation to which it can be applied, was not provided by national criminal legislation.

Contrary to this view, there are opinions that the legal conditions for the application of the institute of command responsibility still exist. Namely, the position is advocated, especially by the Humanitarian Law Center, that the prosecution of persons on the basis of this institute is possible through the direct application of international treaty and customary law, which the Constitution of the Republic of Serbia allows within Article 16. The second basis for the application of this institute is found in Article 30 of the Criminal Code of the Federal Republic of Yugoslavia, according to which the question of liability for inaction, ie omission of an act that the perpetrator was obliged to commit, may be raised. This inaction, ie omission of the superior's actions, refers to non-prevention of crimes of subordinates, ie failure to take measures 
against them, and for whose behavior the superior guarantees. The duty of a superior to do so exists in accordance with the provisions of international law, namely Art. 86 and 87 of Additional Protocol I to the Geneva Conventions of 1977, as well as the provisions of customary international law (or generally accepted rules of international law, in accordance with our constitutional terminology), which provide for command responsibility in internal conflicts and which binds all states and individuals.

Pursuant to the above provisions, on this basis, the War Crimes Prosecutor's Office of the Republic of Serbia issued an order in 2014 to conduct an investigation against the former commander of one of the brigades of the Army of the Federal Republic of Yugoslavia in Kosovo, but it was suspended in 2017. Before this case, ie. Since its inception in 2003, the War Crimes Prosecutor's Office has indicted only high-ranking members of the armed and civilian structures of the Republic of Bosnia and Herzegovina and the Republic of Croatia, but not the Republic of Serbia, contrary to the provisions of the War Crimes Strategy. 2016-2020, adopted by the Republic of Serbia due to the obligations arising from the aforementioned Negotiating Chapter 23. With the mentioned strategy, the Republic of Serbia has committed itself to prosecuting high-ranking military, police and civilian officers in the prosecution of crimes committed during war conflicts, but accordingly With the mentioned reports of the European Commission on the progress of Serbia, our country has not realized that so far.

The application of command responsibility based on the norms of international law is an unavoidable precondition for the successful resolution of a large number of criminal cases involving command responsibility. Although the principle of legality (nullum crimen sine lege) prohibits criminal prosecution for an offense that was not explicitly prescribed as a criminal offense at the time of its commission, an explicit derogation from this prohibition is also prescribed by the European Convention on Human Rights. rights in Article 6 and the International Covenant on Civil and Political Rights in Article 15, according to which criminal offenses may be provided not only by national law but also by international law. The same, in addition to international conventions, includes unwritten generally accepted rules of international law.

Both of these international instruments also stipulate that a sentence heavier than the one that was applicable at the time of the commission of the crime must not be imposed, but they do not require that the exact punishment must be prescribed in advance. Accordingly, even if the Constitution of the Republic of Serbia in Article 34, stipulates that both the crime and the punishment must be prescribed by law at the time of the commission of the crime, according 
to generally accepted rules of international law, the penalty may be imposed within the general minimum and maximum, (which would mean imprisonment for a minimum of fifteen days to between 15 and 20 years for the most serious forms of crime). This approach, from the aspect of national criminal law, is questionable, but it is accepted in international law, the practice of many states, and it has been approved by the European Court of Human Rights.

In addition, the 1992 the Constitution explicitly provided that customary international law was an integral part of the domestic legal order, reinforcing the argument about the "availability and predictability" of customary provisions on command responsibility.

In accordance with these provisions of international law, the War Crimes Prosecutor's Office in 2008 filed a request for an investigation against the now deceased Peter Egner, in connection with the organization and incitement to commit genocide and war crimes during World War II, although a positive right at the time of the commission of these alleged crimes, she was unaware of the crimes of war crimes or genocide. The investigating judge and the panel of the War Crimes Chamber approved the investigation. The judges found that the request for an investigation was not contrary to the principle of legality and the Constitution, although the investigation against Egner was conducted for crimes committed thirty years before the enactment of the Criminal Code of the Socialist Federal Republic of Yugoslavia. Therefore, if customary international law can be directly applied to prosecute war crimes or genocide, even before those acts are provided for as criminal offenses in domestic law, the same principle should be applied to international norms on command responsibility.

However, liability under Article 30 of the Criminal Code of the Federal Republic of Yugoslavia, and if it is clear that it cannot be called "command responsibility", can, as we have already stated, lead to the responsibility of superiors for crimes committed by their subordinates. Namely, the War Crimes Chamber of the High Court in Belgrade has so far applied the theory of liability for non-commission in at least one war crimes case. The case concerns "Zvornik II", in which the War Crimes Department convicted a military commander of aiding and abetting the killing and violating the bodily integrity of detained civilians, whose detention he personally ordered. The accused did not participate in the crimes themselves, which were committed by his subordinates, but the court found that the accused knowingly brought the victims into a state of helplessness by ordering their imprisonment, thus creating an obligation to protect them. According to the court, this obligation creates liability for omission both under Article 30 of the Criminal Code of the Federal Republic of Yugoslavia and under customary international law. 
The case "Zvornik II" refers only to the responsibility arising from the warranty notices to the hostages. Nevertheless, this case represents an important step forward in Serbian case law towards the possibility of prosecuting and convicting superiors only on the basis of domestic provisions in force at the time the crimes were committed.

\section{Concluding remarks}

If we look at the institute of command responsibility within the framework of our national legislation, we come to the conclusion that it is absolutely acceptable, because it is harmonized with the current criminal law provisions, ie the achieved criminal acquis, on which the Criminal Code of the Republic of Serbia is based. However, in the statutes of both ad hoc tribunals, but also in the Rome Statute, this institute is, to put it mildly, "problematic" because it equates the commander with the executor even when he did not know that the forces under his command were committing a crime. he commits it (unconscious negligence), as well as when he does not take the necessary measures to punish the perpetrators, ie when he fails to report the crime to the competent authorities, which is contrary to basic criminal acquis and achievements (principle of individual subjective responsibility, fairness and proportionality), as well as the fact that acts that are within the jurisdiction of these courts as a form of guilt require intent, and even more (intent in the crime of genocide).

In addition to the legal objections raised, in the work, especially of the 1993 Hague Tribunal, the institute of command responsibility is often "politicized". Namely, when the supreme commander of one of the parties in the conflict was tried, the entire army was tried, as well as all those who were subordinate to that commander. On the contrary, when individuals who were in a very low position in the chain of command were tried, the army as a whole was not tried.

Furthermore, we cannot ignore the fact that the work of the ad hoc tribunal and the International Criminal Court, in addition to compromising the institute of command responsibility, also encourages the selectivity of justice, which is mainly exercised over the defeated side. gained that status, had to use more violence in relation to the defeated side. Thus, some crimes remain unprocessed, as if they did not happen (eg the Hiroshima case), while Germany after World War II, as we know, was under strong pressure from the United States to prosecute its citizens for international crimes which they did during World War II.

Second, the selectivity of justice is also expressed by the question why justice only in the case of the former Yugoslavia and Rwanda, and not in the numerous other cases that have taken place? 
The establishment of a permanent International Criminal Court has not solved this problem either, because its jurisdiction depends on the "will" of each country individually, while on the other hand, as it is known, this court suffers open obstruction of its work by the United States.

Regarding the issue of the application of the institute of command responsibility in our country, the courts have ruled on several cases concerning the responsibility of the superior, but a clear position on whether the superior can be held accountable for crimes committed by subordinates, and through which legal mechanism, occupied. The War Crimes Prosecutor's Office and the War Crimes Chamber of the High Court in Belgrade have so far not accepted or rejected the possibility of applying command responsibility in the criminal justice system of Serbia. In a limited number of cases, the institute of liability for omission was applied both under Article 30 of the Criminal Code of the Federal Republic of Yugoslavia and under customary international law. However, a clear position on the issue of superior responsibility (through command responsibility or through inaction) is very much needed, in order to provide legal certainty in criminal justice and to harmonize court practice.

\section{Dinić S. Slavica}

Doktor pravnih nauka, Vanredni profesor na Fakultetu za bezbednost, Univerzitet Educons u Sremskoj Kamenici, Republika Srbija

\section{Turković M. Emil}

Magistar pravnih nauka, Advokat, Asistent na Fakultetu za bezbednost, Univerzitet Educons u Sremskoj Kamenici, Republika Srbija

\section{KOMANDNA ODGOVORNOST}

REZIME: U okviru izlaganja u ovom radu, bavićemo se jednom od niza specifičnosti koje se pojavljuju prilikom utvrđivanja krivične odgovornosti učinilaca međunarodnih krivičnih dela, onom koja je vezana za institut komandne odgovornosti, a koji poznaju statuti oba ad hoc tribunala (statut Haškog tribunala iz 1993. godine i Statut Međunarodnog krivičnog suda za Ruandu iz 1994. godine), kao i tzv. Rimski statut iz 1998. godine, i u okviru kojih je tako postavljen da se, u jednom svom delu, kosi sa osnovnim krivičnopravnim institutima (načelo individualne subjektivne 
odgovornosti, načelo pravednosti). Međutim, ovaj institut, shodno preuzetim međunarodnim obavezama, u svoj kaznenopravni sistem uvela je i Republika Srbija 01. januara 2006. godine, propisivanjem, u okviru člana 384 Krivičnog zakonika Republike Srbije, jednog pravog krivičnog dela propuštanja, a što je takođe predmet obrade ovog rada.

Ključne reči: komandna odgovornost, Rimski statut, ad hoc tribunali, međunarodno krivično pravo.

\section{References}

1. Bejatović, S. (2019). Krivičnoprocesnopravo [Criminal Procedure Law]. Beograd: Službeni glasnik

2. Čejović., B. \& Kulić M. (2012). Krivično pravo [Criminal Law]. Beograd: Službeni glasnik

3. Četvrti izveštaj o sprovođenju Nacionalne strategije za procesuiranje ratnih zločina (2019). [Fourth report on the implementation of the National Strategy for War Crimes Prosecution]. Beograd: Fond za humanitarno pravo. Downloaded 2020, February 20 from http://www.hlc-rdc.org

4. Edlinger, K. (2013). Odabrani dokumenti iz međunarodnog humanitarnog prava [Selected documents from international humanitarian law]. Beograd: Centar za mirovne operacije Vojske Srbije, Međunarodni komitet Crvenog krsta u Srbiji i ISAC fond. Downloaded 2020, June 28 from https://www.isac-fund.org/download/MHP-zbirka_2013.pdf

5. Ilić, R., \& Dinić, S. (2013). Doktrine komandne odgovornosti [Doctrines of command responsibility]. In:Peković, N. (ured.), Haški tribunal-izazovi i realnost: zbornik radova sa savetovanja u Beogradu [The Hague Tribunal - Challenges and Reality: Proceedings of the Conference in Belgrade] (pp. 89-103). Beograd: Udruženje za krivično pravo i kriminologiju Srbije

6. Izveštaj Evropske komisije o napretku Srbije za 2018. godinu [European Commission progress report for Serbia for 2018]. Beograd: Ministarstvo pravde. Downloaded 2020, February 20 from https://www.mei.gov.rs/ upload/documents/eu_dokumenta/godisnji_izvestaji_ek_o_napretku/ izvestaj_ek_o_srbiji(1).pdf

7. Konvencija o ljudskim pravima [Convention on Human Rights]. Strazbur: Savet Evrope, Evropski sud za ljudska prava. Downloaded 2020, May 20 from https://www.echr.coe.int/Documents/Convention_SRP.pdf 
8. Krivični zakonik Republike Srbije [Criminal Code of the Republic of Serbia]. Službeni glasnik $R S$, no. 85/05, 88/05-ispr., 107/05-ispr., 72/09, 111/09, 121/12, 104/13, 108/14, 94/16, 35/19

9. Krivični zakon Savezne Republike Jugoslavije [Criminal Code of the Federal Republic of Yugoslavia]. Službeni list SFRJ, no. 44/76, 36/77 - ispr., 34/84, 37/84, 74/87, 57/89, 3/90, 38/90, 45/90 - ispr. i 54/90 i Službeni list SRJ, no. 35/92, 16/93, 31/93, 37/93, 41/93, 50/93, 24/94 and $61 / 01$

10. Serbia 2019 Report [Izveštaj o Srbijiza 2019. godinu]. Brussels: European Commision. Downloaded 2020, February 20 from https:/ec.europa.eu/ neighbourhood-enlargement/sites/near/files/20190529-serbia-report.pdf

11. Stojanović, Z. (2020). Krivično pravo - opšti deo [Criminal Law General Part]. Beograd: Pravni fakultet Univerziteta u Beogradu

12. Stojanović, Z. \& Delić, N. (2020). Krivično pravo-posebni deo [Criminal Law - Special Part]. Beograd: Pravni fakultet Univerziteta u Beogradu

13. Škulić, M. (2015). Krivično procesno pravo [Criminal Procedure Law]. Beograd: Pravni fakultet Univerziteta u Beogradu

14. Ustav Republike Srbije [Constitution of the Republic of Serbia]. Službeni glasnik $R S$, no. 98/06

15. Ustav Savezne Republike Jugoslavije [Constitution of the Federal Republic of Yugoslavia]. Službeni list SFRJ, no. 1/92

16. Zakon o potvrđivanju Rimskog statuta Međunarodnog krivičnog suda [Law on Ratification of the Rome Statute of the International Criminal Court]. Službeni list SRJ - Međunarodni ugovori, no. 5/01

17. Zakon o ratifikaciji Međunarodnog pakta o građanskimi političkim pravima [Law on Ratification of the International Covenant on Civil and Political Rights]. Službeni list SFRJ, no. 7/71 